\title{
Which post-Westphalia? International organizations between constitutionalism and authoritarianism
}

\author{
European Journal of \\ International Relations \\ 20I5, Vol. 2I(3) 568-594 \\ (C) The Author(s) 2014 \\ Reprints and permissions: \\ sagepub.co.uk/journalsPermissions.nav \\ DOI: 10.1 I 177/I354066 I | 4548736 \\ ejt.sagepub.com \\ @AGE
}

\author{
Christian Kreuder-Sonnen \\ WZB Berlin Social Science Center, Germany
}

\section{Bernhard Zangl}

Ludwig-Maximilians-Universität München, Germany

\begin{abstract}
The most recent transformation of world order is often depicted as a shift from a Westphalian to a post-Westphalian era in which international organizations are becoming increasingly independent sites of authority. This internationalization of authority is often considered as an indication of the constitutionalization of the global legal order. However, this article highlights that international organizations can also exercise authority in an authoritarian fashion that violates the same constitutionalist principles of human rights, democracy, and the rule of law that international organizations are usually expected to promote. It is thus an open question which post-Westphalia we are in fact heading to: a constitutionalized order, an authoritarian order, or a combination of both? Based on a conceptualization of post-Westphalian orders as a two-dimensional continuum linking the ideal-typical end points of constitutionalism and authoritarianism, we analyze the United Nations security system and the European Union economic system as two post-Westphalian orders. While we find a remarkable level of constitutionalization in the European Union and incipient constitutionalist tendencies in the United Nations, we also find authoritarian sub-orders in both institutions. Most visibly, the latter can be discerned in the United Nations Security Council's counter-terrorism policy after $9 / 1 \mathrm{I}$ and European emergency governance during the sovereign debt crisis. The article thus argues that the emerging post-Westphalian order is characterized by a plurality of fundamentally contradictory (sub-)orders coexisting in parallel.
\end{abstract}

\section{Corresponding author:}

Christian Kreuder-Sonnen, WZB Berlin Social Science Center, Research Unit Global Governance,

Reichpietschufer 50, 10785 Berlin, Germany.

Email: christian.kreuder-sonnen@wzb.eu 


\section{Keywords}

Authoritarianism, European Union, international authority, international organizations, post-Westphalian order, United Nations Security Council

\section{Introduction}

The most recent trend in the transformation of world order is often depicted as a shift from Westphalia to post-Westphalia. According to this conception, the Westphalian order consisting of sovereign authorities that interact under conditions of anarchy gives way to a post-Westphalian order marked by internationalized authority structures. ${ }^{1}$ This is not to say that a centralized world state is in the making. The emerging post-Westphalian order remains fragmented: issue area-specific (sub-)orders continue to coexist (Biermann et al., 2009; Fischer-Lescano and Teubner, 2004). Yet, within some (sub-)orders, international organizations (IOs) gain in political authority and, thus, increasingly introduce vertical elements into the otherwise horizontal international order (Genschel and Zangl, 2014; Hooghe et al., forthcoming; Kumm, 2004: 913-915; Zürn et al., 2012).

Interestingly, many have taken the increasing authority of IOs as an indication of a constitutionalization of the international order through which the principle of state sovereignty is substituted by the constitutional principles of democracy and the rule of law (Wiener et al., 2012). The most prominent examples include the strengthening of parliamentary democracy and judicial review in the European Union (EU) or the institutionalization of more stakeholder participation and/or better accountability mechanisms in the United Nations (UN), the World Trade Organization (WTO), and the World Bank (WB) (Armingeon et al., 2011; Cass, 2005; Naudé Fourie, 2009; Petersmann, 1996/1997; Schimmelfennig and Rittberger, 2006; Stone Sweet, 2000). Even contrasting theoretical approaches such as liberal internationalism and critical neo-Marxism, which differ fundamentally in their normative assessments of constitutionalism, agree that the internationalization of political authority coincides with its constitutionalization. Liberal internationalists endorse global constitutionalization as a step away from anarchical state voluntarism to a law-based international order, which may also rectify domestic democracy and accountability deficits triggered by globalization (Fassbender, 1998; Keohane et al., 2009; Klabbers et al., 2009; Peters, 2006). Critical theorists, by contrast, interpret global constitutionalization as an attempt to hide the exercise of power through international law (May, 2014; Rajkovic, 2012) and to lock in IO authority structures that "militate against solidarity and social justice" (Gill and Cutler, 2014: 9; see also Chimni, 2004: 1-19; Schneiderman, 2000).

What is, thus, rarely taken into account by either liberal internationalists or critical theorists is that increasing IO authority does not necessarily entail their constitutionalization. Increasing IO authority may indeed drive the institutionalization of democracy and the rule of law, but - as in any other polity — it may also come with authoritarian rule. In fact, some IOs sometimes exercise authority in an authoritarian fashion that violates the same constitutional principles of democracy and the rule of law that IOs are usually 
expected to promote (see also Chimni, 2004: 19-23). For example, the United Nations Security Council's (UNSC's) reaction to the 9/11 terrorist attacks demonstrated "quasidictatorial" traits when it assumed legislative competencies and began to blacklist terror suspects in order to freeze their bank accounts (Cohen, 2012: 266-283; Kreuder-Sonnen, 2012). By the same token, European emergency measures to counter the sovereign debt crisis in the Eurozone followed largely undemocratic and legally questionable decisionmaking procedures (Joerges and Weimer, 2013; White, 2013). Furthermore, even the World Health Organization (WHO) showed "autocratic tendencies" when it managed the swine flu "epidemic" in 2009 based on emergency decisions (Deshman, 2011; Hanrieder and Kreuder-Sonnen, 2014). Contrary to any plausible understanding of constitutionalization, in these cases, IOs exercised authority in an autocratic and/or arbitrary fashion. While these authoritarian acts of IO authority are not completely ignored in the literature, they are usually treated as if they were isolated and singular "scandals" (Bast and Rödl, 2012; Cohen, 2008; Duncan, 2013; Elberling, 2005; Fidler, 2004: 268; Hudson, 2007; Joyner, 2012; Ryvkin, 2012; Stark, 2012). We argue, by contrast, that they belong to a class of IO orders that share a common grammar of authoritarianism. As such, these orders could be indicative of a post-Westphalian order based on authoritarian - rather than constitutionalist — principles.

Hence, the question we pose is not whether we are experiencing a transformation from a Westphalian to a post-Westphalian order. We rather look at IOs that enjoy supranational authority 2 in order to ask: which post-Westphalian order are we actually heading to? Is it a constitutionalized or an authoritarian order? We argue that it is a combination of both: post-Westphalia reflects not only constitutionalist principles of democracy and the rule of law, but also authoritarian principles of autocracy and arbitrary rule. The emerging post-Westphalian order is thus characterized by a plurality of fundamentally contradictory (sub-)orders coexisting in parallel. To substantiate this claim, the article is structured as follows. In a first step, we lay out a typology of global legal orders and argue that there are indications of a gradual shift away from a purely horizontal, and thus intergovernmental or Westphalian, to a more vertical, and thus supranational or post-Westphalian, structure of the global legal order. In a second step, we conceptualize constitutionalized and authoritarian orders as the poles of a gradual scale of post-Westphalian order and introduce criteria to locate IO authority between these poles. In a third step, we assess, based on these criteria, the legal orders of the EU economic and the UN security systems. We show that gains of IO authority went along with parallel trends toward more constitutionalized and more authoritarian traits. In the conclusion, we hint at avenues for further research.

\section{From Westphalia to post-Westphalia: Four conceptions of global legal order}

To describe transformations of the international order, we distinguish four fundamentally different types of order, each of which describes a specific legal arrangement of how political authority may be exercised. ${ }^{3}$ The typology rests on two fundamental distinctions that gave rise to critical debates in legal scholarship about the institutionalization of political authority. 
First, legal orders can be distinguished according to whether authority relations are structured horizontally or vertically. A legal order based on horizontal relations between equal authorities is to be contrasted with one that contains vertical elements, that is, some form of superior authority whose acts are legally binding without or even against the constituents' will. John Austin (2005 [1885]) and Hans Kelsen (2003 [1952]) held that in order to be authoritative, and thus dubbed law proper, norms had to be integrated in a vertically structured order that is able to ensure reliable enforcement. By contrast, others claim that enforcement is not a necessary condition for law to exist and to have an impact (Alexy, 1992; Hart, 1994). According to this view, there may be horizontally structured orders with decentralized authority that unfold their effect via the incentive structures for the actors involved (Höffe, 1987; Kant, 2009 [1797]: VI, 232-233).

Second, legal orders are to be distinguished according to whether political authority (exercised horizontally or vertically) is constituted and constrained by law. On the one hand, there are legal orders in which the legality of an act is decisive for its validity. If an act of the authorities is in breach of the law, it will lead the system to repel the matter. Political authority is thus not just legally constituted, but also legally constrained. On the other hand, there are also legal orders in which the political authorities are not necessarily constituted or constrained by law. Here, the system grants basically unlimited discretion to the power-holders. This distinction is one that also gave rise to fierce debates in legal scholarship, most exemplary between Hans Kelsen (1931) and Carl Schmitt (1996 [1931]), who argued about the ultimate guardian of the constitution. While the legalist Kelsen wanted the constitutional court to fulfill this function, the decisionist Schmitt propagated presidential powers. Schmitt argued that in order to maintain stability and thus to save the constitution in times of emergency, it was necessary that the executive enjoyed its prerogatives freely — not with its hands tied by law — to accomplish the necessary. Against this, Kelsen maintained that it was precisely the power of the executive that ought to be constrained by law, since it was the most prone to violate the constitution in the first place.

Crossing the two distinctions - horizontal versus vertical authority structure and legal versus decisionist authority - we arrive at a typology of global legal orders (see Table 1), which can be understood as reflecting overlapping stages in the history of the international legal order (see also Wendt, 1999: 246-312).

While the once-dominant anarchical and contractual orders have not lost their relevance, we nevertheless observe a gradual shift away from these Westphalian orders (see also Dreher et al., 2008; Held, 1999). There is a tendency away from purely horizontal intergovernmentalism toward more vertical forms of supranational authority. Three developments of this post-Westphalian shift are of particular relevance (Genschel and Zangl, 2014; Hooghe et al., forthcoming; Zürn et al., 2012):

1. We observe an increasing pooling of authority in IOs. Decision-making is transferred to collective IO bodies in which individual states lose their power to veto (Lake, 2007). One example is the successive introduction of qualified majority voting in the Council of the EU. However, the erosion of the principle of unanimity is generally observable in more and more IOs (Blake and Lockwood Payton, 2014). For instance, the WTO ministerial conference may take decisions by a 
Table I. Conceptions of global legal order.

\begin{tabular}{|c|c|c|c|}
\hline & Decisionist authority & Legal authority & \\
\hline $\begin{array}{l}\text { Vertical (supranational) } \\
\text { authority structure }\end{array}$ & Authoritarian order & $\begin{array}{l}\text { Constitutionalized } \\
\text { order }\end{array}$ & $\begin{array}{l}\text { Post-Westphalian } \\
\text { order }\end{array}$ \\
\hline $\begin{array}{l}\text { Horizontal } \\
\text { (intergovernmental) } \\
\text { authority structure }\end{array}$ & Anarchical order & Contractual order & Westphalian order \\
\hline
\end{tabular}

majority vote, and the UNSC is also taking more and more majority decisions as its permanent members are less prone to employ their right to veto.

2. The delegation of authority to IO bodies is increasing. IO member states grant authority to supranational bodies such as IO secretariats, courts, or commissions (Hawkins et al., 2006; Hooghe et al., forthcoming). Examples include the European Commission and the Court of Justice of the European Union (CJEU). However, the increasing delegation of authority is also a more wide-ranging, albeit uneven, trend across IOs (Hooghe et al., forthcoming). Well-known examples include the delegation of authority to the WTO's Appellate Body or the International Criminal Court (Deitelhoff, 2009; Zangl, 2008).

3. IOs have substantially extended the intrusiveness of their political authority into states' domestic affairs. As Barnett and Finnemore (2004: 1) note: "[IOs] now work extensively in domestic governance issues, overseeing matters that once used to be the prerogatives of states" (see also Raustiala and Victor, 2004). The WTO, for instance, has even begun to deal with issues such as copyright infringement, public procurement, and corporate taxation, which clearly used to be state prerogatives. By the same token, the UNSC no longer takes measures only against states, but also against groups and even against individuals that are considered to be a threat to peace (Cortright and Lopez, 2000).

To be sure, in large part, the global legal order continues to follow Westphalian intergovernmentalism, with post-Westphalian supranationalism remaining the exception. We nevertheless want to zoom in on post-Westphalian orders and analyze to what extent supranational IOs reflect constitutionalist or authoritarian characteristics.

\section{Dimensions of constitutionalized and authoritarian orders}

For the purpose of analyzing post-Westphalian orders, we conceptualize constitutionalism and authoritarianism as ideal types that constitute opposite poles on a gradual scale of supranational IO authority. To do so, we draw on the respective political philosophies of constitutionalism and authoritarianism, which are reconstructed as normative theories, but employed for analytical purposes only. We use them to construct ideal types of legal orders and to derive criteria for the assessment of the degree to which specific orders conform to these ideal types. This is why we do not engage in any meaningful discussion of the normative implications and theoretical complexities of the respective philosophies, ${ }^{4}$ but simply sketch the fundamentals of their most prominent 
representations, that is, "liberal" constitutionalism in a Kantian tradition on the one hand, and statist authoritarianism in the tradition of Hobbes and Schmitt on the other. ${ }^{5}$

Constitutionalism argues that the relations between the political authorities and the subjects in a given polity should be ordered according to certain superior legal principles that constitute and constrain the exercise of public power. More specifically, it holds that all acts of political authority should be an expression of popular sovereignty and compatible with individual liberty (Kay, 1998: 19). Constitutionalism therefore requires that political authority be constituted by law through democratic legislative processes, while at the same time the wielding of political authority needs to be constrained by law through judicialized processes. In its ideal-typical form, then, constitutionalism argues, first, that the constitution of political authority should follow a legal process that allows all individuals subject to the respective authorities to be equally represented and to freely participate in open deliberations. Second, it holds that political authority should be constrained by law and be subjected to judicial review that provides access to all individuals affected by the respective acts of authority (Habermas, 1996; Kant, 2007 [1795]; Kelsen, 1931).

Authoritarianism, by contrast, holds that the stability of political order is of utmost importance for individual and collective security, especially in cases of emergency. Any breakdown of political authority is assumed to result in anarchic conditions under which all individuals pose an imminent threat to each other's security (Hobbes, 2008 [1651]). In the interest of each individual's security, authoritarianism thus advocates the concentration of powers in the hands of executive authorities in order to guarantee stability. These authorities ought to do whatever is necessary - not what is legal — to ensure individual and collective security. It must thus be up to the power-holder itself to determine its own competencies. In its ideal-typical form, then, authoritarianism argues, first, that the constitution of authority may result from an act of autocratic self-empowerment and, second, that authority is to be exercised independently of any legal constraints, with full discretion over how to preserve the order (Hobbes, 2008 [1651]; Machiavelli, 2008 [1532]; Schmitt, 2014 [1928]).

Thus, both political philosophies of constitutionalism and authoritarianism concern the procedural question of how political authority should be constituted and constrained. While constitutionalism advocates that authority be constituted in a democratic fashion and constrained by the rule of law, authoritarianism justifies the autocratic constitution and arbitrary operation of authority. Therefore, the distinction between constitutionalism and authoritarianism is not about the assessment of the substantive policies that may or may not be adopted in a given order. In fact, political authority can always produce "good" and "bad" policies irrespective of whether it is structured according to constitutionalist or authoritarian principles. The distinction is about the legal procedures through which authority is constituted and through which exercising authority is constrained.

To adequately grasp the empirical reality of IO authority, we conceive the ideal types of constitutionalized and authoritarian orders as the poles of two gradual scales:

- a first scale that indicates to what extent IO authority is constituted in a democratic or autocratic fashion; and

- a second scale that defines to what extent the exercise of IO authority is constrained by the rule of law or allows for arbitrary rule. 


\section{Democracy \\ Democratic: Authority is constituted by a legal process that ensures public deliberation and equal representation \\ Partially democratic: Authority is constituted by a legal process that ensures some public deliberation but only limited representation \\ Hybrid: Authority is constituted by a legal process characterized by strongly limited deliberation and representation \\ Partially autocratic: Authority is constituted by a legal process that undermines the legal authority structure, justified by political necessity (legal usurpation) \\ Autocratic: Authority is constituted by self-empowerment that abrogates the existing authority structure, justified by political necessity (extra-legal usurpation) \\ Autocracy}

Figure I. Levels of democratic and autocratic constitution of authority.

\section{The constitution of authority}

The scale for the assessment of the constitution of authority in a given IO (sub-)order distinguishes between five levels, ranging from democracy (constitutionalized order) to autocracy (authoritarian order) (see Figure 1):

- Democratic: A legal order is democratic if political authority is constituted in a legal process that ensures both equal representation and public deliberation. Open to the — direct or indirect — participation of all rule-addressees, this process encourages the legislature to give reasons for binding law in terms of the common good only. This level of democracy is quite exceptional for IOs. The EU, with the directly elected European Parliament, is the only serious candidate (Rittberger, 2005).

- Partially democratic: The constitution of authority is partially democratic if its legislative process ensures public deliberation, but only limited representation. The legislature is stimulated to justify the law in terms of the common good, but only through the limited participation of rule-addressees. Limited participation may imply that there is no legal right to participate but a procedure according to which the political authorities invite the participation of self-selected addressees rather than elected representatives. Limited participation may also imply that addressees only need to be consulted, but that they ultimately have no formal say in the process. Nowadays, many IOs allow non-state actors to participate in their legislative processes as observers without voting rights, which makes them more open to the eye of the general public, thereby enabling public deliberations (Uhlin and Tallberg, 2012).

- Hybrid: The constitution of authority is hybrid when it is based on non-transparent legal processes that suffer from limited participation and deliberation. In IOs, this 
has been the rule: under so-called "executive multilateralism" (Zürn, 2004), decisions were taken by state representatives behind closed doors so that the legislative process was not required to give reasons in terms of the common good; states may rather simply refer to the national interest.

- Partially autocratic: The constitution of authority is partially autocratic if it follows predefined legal procedures, but undermines the legal authority structure on which the order is built. The introduction of the Excessive Imbalances Procedure (EIP) by the EU legislature in 2011 might be illustrative of such a "legal usurpation" of authority. To cope with the euro crisis, Parliament and Council established an unofficial European economic government, thereby altering through secondary law the balance of power between the Council and Commission as originally defined by the primary law of the European treaties (Bast and Rödl, 2012).

- Autocratic: The constitution of authority is autocratic when it results from an act of self-empowerment that abrogates the pre-existing authority structure. Unlike in a partially autocratic order, the constitutive act does not conform to a legal process, but amounts to an extra-legal usurpation of authority justified, for instance, by exceptional necessity. The WHO's reaction to the SARS crisis of 2002/2003 is a case in point. Based on the assessment of SARS as a "worldwide health threat," then Director-General Gro Harlem Brundtland decided to issue travel warnings without the legal authority to do so (Cortell and Peterson, 2006; Fidler, 2004: 268; Hanrieder and Kreuder-Sonnen, 2014: 337).

\section{The constraints on authority}

The scale for the assessment of the constraints on political authority in a given IO is defined by five levels, ranging from judicialized (constitutionalized order) to arbitrary rule (authoritarian order) (see Figure 2):

- Judicialized: The constraints on authority are judicialized if every act of authority is constrained by substantive legal norms and subject to binding independent judicial review providing open access to the rule-addressees, be they individual or collective, public or private. EU competition law is illustrative here because the European Commission has the authority to sanction private companies violating competition law while, at the same time, being bound to operate within the narrow confines set by law. Otherwise affected companies may file a complaint with the CJEU, which may revoke the sanction in case it finds that the Commission has acted in violation of the complainant's rights (Schweitzer, 2013).

- Partially judicialized: Political authority is partially judicialized when acts of authority are subject to limited judicial review only. Limited judicial review may imply that it does not provide access for the addressees of these acts. It may also imply that authority acts can merely be reviewed by a third party such as an ombudsperson or a committee that does not enjoy the political independence or binding jurisdiction of courts. The WB, whose projects have to conform to set policy principles - so-called operational policies and procedures - may serve as an example because it has its own Inspection Panel that can be activated by 
Rule of law

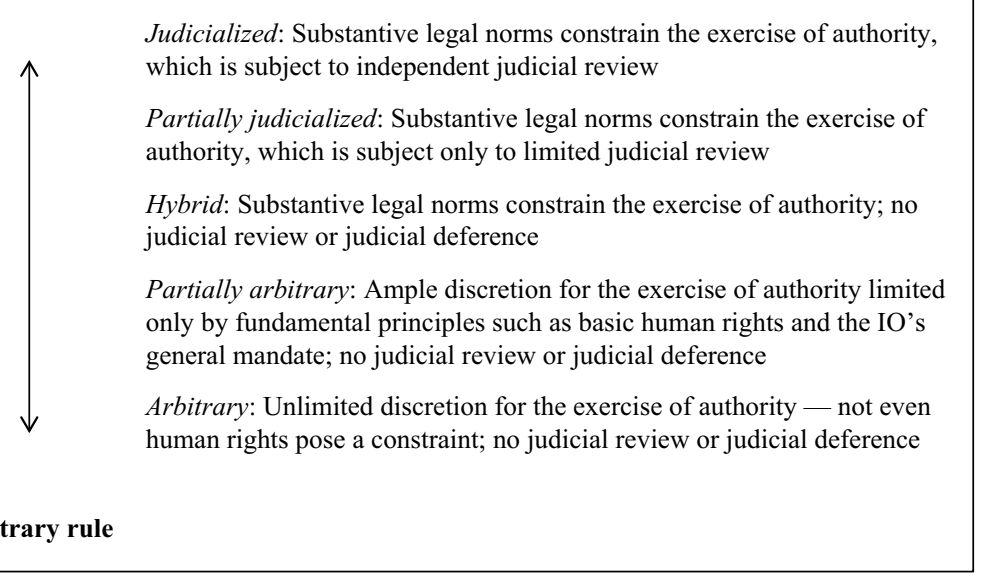

Figure 2. Levels of judicialized and arbitrary constraints on authority.

individuals who claim that a WB-funded project contravenes these principles. However, the Inspection Panel can only issue non-binding recommendations to the Executive Board (Naudé Fourie, 2009).

- Hybrid: We call constraints on authority hybrid if acts of authority, while formally committed to conform to the law, are not subject to judicial review. Affected actors may be able to criticize acts of authority that disregard the law in the general public, but there is no effective judicial review. This holds true for most IOs. While they have to respect international law in principle, there is no institutionalized remedy that affected individuals or states can draw on in case an IO disrespects this commitment.

- Partially arbitrary: We conceive of a legal order as partially arbitrary if the exercise of authority is mostly freed from legal constraints and thus enjoys ample discretion. Only very fundamental legal principles such as jus cogens and a core canon of human rights, as well as the overall mandate of the institution wielding authority, may function as limits. The European border control agency FRONTEX may serve as an example. FRONTEX is clearly bound by its mandate, as well as core human rights, but by diverting refugee ships without even considering the passengers' potential refugee status and denying due legal protection, the agency has factually carved out an area free of legal constraint (Fischer-Lescano et al., 2009).

- Arbitrary: The exercise of authority is arbitrary if it is granted virtually unlimited discretion. Here, not even fundamental human rights mark a legal constraint on the authority's prerogatives. While very rare in IOs, the infringement of individual rights by the UNSC's practice of targeted sanctions without any mechanism of legal review could provide an example (Hudson, 2007; Kreuder-Sonnen, 2012: 69-74). 


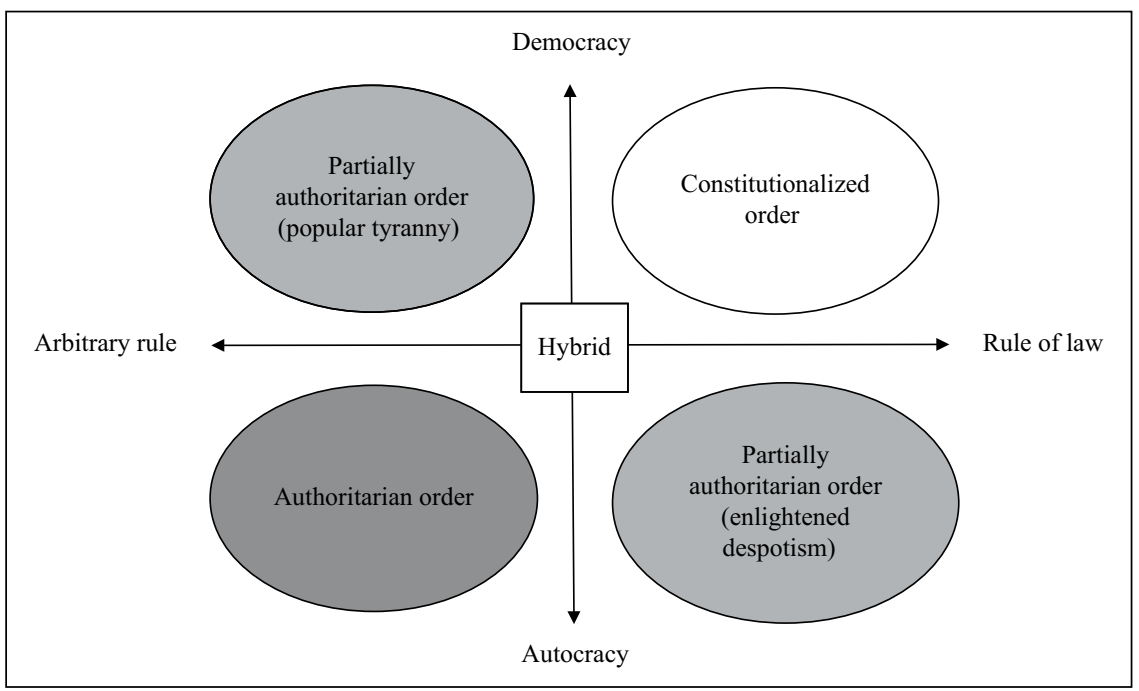

Figure 3. Post-Westphalian orders according to the constitution of and constraints on 10 authority.

This conceptualization of two gradual scales of post-Westphalian order — one with regard to the constitution of authority and one with regard to the constraints on authority - should allow the assessment of the constitutionalist or authoritarian quality of IO (sub-)orders (i.e. legal regimes). It should be noted that the two dimensions are conceptually independent from each other. It is conceivable that a legal order is democratic with regard to the constitution of authority while its operation is arbitrary in terms of legal constraints. It is equally conceivable that a legal order is autocratic with regard to the constitution of authority while institutionalizing legal constraints through judicial review mechanisms. However, we would consider both these orders as partially authoritarian because the rule of law and democracy are two necessary complements for any constitutionalized legal order: they are "co-original" (Habermas, 1996: 84-103; see also Krisch, 2010: 50). ${ }^{6}$ As soon as one dimension tilts toward authoritarianism, the system is stripped off its constitutional quality and becomes either "enlightened despotism" or "popular tyranny" (see Figure 3).

\section{Post-Westphalian orders between constitutionalism and authoritarianism}

Based on the preceding conceptualization, we can now assess the extent to which postWestphalian authority structures in the current international order follow constitutionalist or authoritarian principles. As we obviously cannot analyze the international order in its entirety, we instead look at the legal (sub-)orders of two important IOs, namely, the EU economic and the UN security regimes. We selected these IO sub-orders mainly because they are obvious cases of supranational authority. The main purpose of the ensuing analysis is to illustrate that our conceptualization is useful for the assessment of 
supranational authority. ${ }^{7}$ We also claim, however, that the analysis of the EU and UN allows some, albeit limited, inference to other IOs with supranational authority, because they differ along several dimensions: first, the EU is a regional organization, while the UN acts globally; second, the issue areas covered by the EU and the UN do indeed overlap, but the EU nevertheless treats mostly economic issues whereas the UN focuses more on security issues; and, third, the EU, as the most integrated IO, is more supranationalized than the UN. In the spirit of a most-different-case design, we assume that comparable constitutionalized and/or authoritarian sub-orders across fundamentally different IOs may indicate that similar features can also be found in other IOs.

\section{UN security system}

While the UN security system, with the UNSC at its core, is still characterized by intergovernmental structures, with the end of the Cold War, it has experienced a considerable shift toward more supranational authority (Cronin and Hurd, 2008). First, the UN is increasingly taking intrusive decisions on matters far beyond traditional interstate security, nowadays intervening broadly to safeguard so-called human security (Malone, 2004; Matheson, 2006). Second, the UNSC pools member states' decision-making authority. No longer suffering from the Cold War blockade, today the UNSC takes binding majority decisions with only its five permanent members having the opportunity to veto them. Third, UN member states delegate authority to supranational UN organs and agencies. The UN-led transitional authority in Kosovo or the UN-installed Blix Commission on Weapons of Mass Destruction (WMD) in Iraq may serve as examples. However, this post-Westphalian shift was hardly accompanied by a corresponding constitutionalization of the UNSC's authority. In fact, as originally designed in the UN Charter, it rather started to operate as a partially authoritarian institution.

To be sure, with regard to the constitution of authority, the UN security system is generally to be considered hybrid. According to the Charter, decision-making by the UNSC is tied to clearly defined legal procedures. The UNSC adopts resolutions by a qualified majority, requiring nine positive votes out of its 15 members, giving only its five permanent members the right to veto. In order to take binding decisions under Chapter VII of the Charter, the UNSC has to fulfill formal and substantial requirements, for example, the establishment of the existence of a threat to peace (Krisch, 2012). While the UNSC is bound to follow this legal process, its democratic credentials are virtually non-existent. To be sure, UNSC decision-making has opened up to more stakeholder participation over the last decades; it developed procedures of regular informal consultation with non-governmental organizations (NGOs) (Binder, 2008; Paul, 2004) and the UNSC's debates are said to have gained in deliberative quality (Johnstone, 2008). Yet, the bulk of its decisions are still made in a non-democratic process based on interstate negotiations held behind closed doors and dominated by the permanent members.

Moreover, as far as the constraints on its authority are concerned, the UN security system even reflects authoritarian principles: the exercise of authority by the UNSC can be considered partially arbitrary (see Koskenniemi, 1995). While legally bound by the Charter and thus arguably also by fundamental human rights (De Wet, 2001: 284; Shaygan, 2008: 181-183), the UNSC is generally entrusted with ample discretion in 
fulfilling its mandate to protect international peace and security. In fact, in case of a threat to peace, the Charter explicitly provides the UNSC with far-reaching "emergency powers," while, at the same time, giving it ample discretion to decide whether a specific situation amounts to a threat to peace (Chesterman, 2009; Schott, 2007). Thus, after having defined a situation as a threat to peace, the UNSC is basically at liberty to decide on any measure as long as it is necessary and appropriate to counter the threat (Krisch, 2012). Moreover, even the extremely limited legal constraints that the UNSC faces are hardly subject to any form of judicial review. The International Court of Justice (ICJ), which is the primary judicial organ of the $\mathrm{UN}$, has jurisdiction only in contentious cases between states (cf. Alvarez, 1996). It is only through the judicial review of member states' implementation of UNSC decisions by domestic courts that singular UNSC decisions are legally scrutinized. However, while binding for these member states' authorities, these court decisions are not binding for the UNSC. As with the incidental judicial review of UNSC decisions through ICJ advisory opinions or through the International Criminal Tribunal for the former Yugoslavia (ICTY), member states' court decisions may have some political impact, but no legal bearing on the UNSC (Aust, 2008; Heupel, 2013). Hence, not even affected states, let alone affected individuals, have any effective remedies for challenging UNSC measures in court.

Overall, the UNSC's shift toward post-Westphalia established a partially authoritarian order that is accompanied by a marginal process of constitutionalization with regard to the constitution of authority, but hardly with regard to the constraints on authority. As the following analysis of, first, the UNSC counter-terrorism regime and, second, the UNSC non-proliferation regime will show, however, the UNSC has even managed to institutionalize fully authoritarian sub-orders.

The UNSC counter-terrorism regime. In the domain of counter-terrorism, the constitution of authority by the UNSC followed autocratic principles. The UNSC, meant to be an executive organ, empowered itself to act as a global legislature (Cohen, 2008). After the 9/11 terrorist attacks, which the UNSC interpreted as a threat to peace, in Resolution 1373 (2001), it decreed abstract and general provisions especially entailing the duty of all member states to criminalize any form of logistic or financial support for terrorists (Szasz, 2002). Thereby, the UNSC did not simply enforce already-existing international law; rather, it created international law from scratch. In fact, it made provisions for a draft treaty on international counter-terrorism binding for all UN member states, though the negotiating parties had been unable to agree on these provisions (Bantekas, 2003: 326). The UNSC thus bypassed regular international law-making procedures based on state consent and assumed law-making competencies. Given its discretionary powers, this may or may not be seen as an act ultra vires in purely legal terms, but, in fact, the UNSC "usurped" legislative powers beyond its executive function and thus abrogated the authority structure as provided in the Charter (Elberling, 2005; Fremuth and Griebel, 2007; Rosand, 2004: 567): "The constituted power transforms itself ... into the constituent power, to the total subversion of constitutionalism" (Arato, 2012: 654; see also Cohen, 2012: 279-280).

Yet, the UNSC not only redefined the scope of its own authority, it also created an area devoid of legal constraints on its authority. While it already enjoys wide discretion for the exercise of authority by design of the Charter, the UNSC carved out a realm of 
unlimited discretion in its counter-terrorism regime. Drawing on Resolution 1267 (1999), which was meant to enforce the extradition of Osama bin Laden from Afghanistan, UNSC Resolution 1390 (2002) founded a broader regime of "targeted" sanctions addressing individual terror suspects (Heupel, 2007). Central to this regime is a blacklist containing the names of terror suspects. Once on the list, an individual is subject to severe financial restrictions - bank accounts and other financial assets are frozen - and a travel ban. While listed individuals are informed about their listing, no evidence is presented for their involvement in terrorist activities (Hoffmann, 2008). Moreover, it was only through the introduction of an ombudsperson by Resolution 1904 (2009) that the delisting procedure has become a viable option for listed individuals (Heupel, 2013). However, this procedure not only confirms the regime's reversal of the burden of proof that violates the presumption of innocence, but also violates the right to a fair hearing by an independent and impartial tribunal, as provided by international human rights law (Cameron, 2005; Fassbender, 2006; Hudson, 2007).

The UNSC non-proliferation regime. With regard to the proliferation of WMD, the UNSC developed a similarly authoritarian order (for an overview, see Fry, 2008). As in the domain of counter-terrorism, the UNSC acted as an undue legislature, which seized lawmaking powers autocratically by executive self-empowerment in order to constitute its authority. After the uncovering of the clandestine nuclear smuggling network around the Pakistani physicist Abdul K. Khan, the UNSC adopted Resolution 1540 (2004) concerning the proliferation of WMD to non-state actors. The resolution forces states to adopt domestic law criminalizing the acquisition of WMD by and the transfer of WMD to nonstate actors. The UNSC expressly justified Resolution 1540 as an exceptional measure to close gaps in the international legal order governing non-proliferation. ${ }^{8}$ It thus openly admitted that it did not act as an executive body that implements existing law, but as a legislature amending the law (Asado, 2009; Joyner, 2012: 237; Martínez, 2008). Arguably, the deliberative quality of this law-making process was higher than the one leading to the adoption of Resolution 1373 on counter-terrorism measures: two open debates were held giving any UN member the opportunity to voice concerns (Johnstone, 2008). However, these debates were nothing but a "fig leaf" since the resolution had already been drafted by the permanent members and remained unchanged despite criticism by many state representatives whose concerns were dispelled by reference to the exceptional circumstances necessitating emergency legislation (see Kreuder-Sonnen, 2012: 96-99). ${ }^{9}$ Furthermore, even if the debates had had an impact on the resolution, it was not for the UNSC as executive organ to usurp legislative authority.

Moreover, some UNSC measures to prevent the proliferation of WMD can be considered arbitrary because they transgress legal constraints on the UNSC's authority. Resolutions 1718 (2006) and 1874 (2009) concerning the nuclear program of the Democratic People's Republic of Korea (DPRK) are a case in point. Reacting to the DPRK's withdrawal from the Nuclear Non-Proliferation Treaty (NPT) in 2003 and two subsequent nuclear weapon tests in 2006 and 2009, the resolutions basically commanded the DPRK to abide by the terms of the NPT and to accept a safeguards agreement with the International Atomic Energy Agency (IAEA). The UNSC issued these resolutions despite the fact that North Korea's previous withdrawal from the NPT had restored its 
sovereign right to possess nuclear weapons (Carlson, 2008; Fry, 2008: 265-269; Joyner, 2012: 248-251). Moreover, the UNSC did more than temporarily suspend the country's right to possess WMD in order to cope with a specific threat to peace; this would have been clearly within its mandate. With Resolution 1874, however, the UNSC permanently suspended the country's right to possess WMD without any possibility for North Korea to legally challenge this decision (Joyner, 2012: 251).

UNSC Resolution 1737 (2006) concerning Iran's nuclear program provides another example of arbitrary acts that go beyond the legal constraints on UNSC authority. While at first glance similar to the DPRK case, the Iran case is different because the country never revoked the NPT. Indeed, as opposed to North Korea, Iran does not have the right to develop or possess nuclear weapons and must abide by the reporting and inspections requirements under the IAEA safeguards agreement (Fry, 2008: 271-276). Failing on the latter led the IAEA to refer the issue to the UNSC, which then, in Resolution 1737, not only urged Iran to comply with its obligations under the safeguards agreement, but also required the immediate suspension of all its uranium enrichment-related and reprocessing activities. To be sure, the UNSC may force Iran to comply with its obligations under the safeguards agreement if its violation can be regarded as a threat to peace, but as the NPT confirms states' inalienable right to use nuclear energy for peaceful purposes, it cannot simply require that Iran refrains from all uranium enrichment-related and reprocessing activities for an unlimited time period. As Joyner (2012: 246) summarizes: "by trampling upon a right of states recognized in a broadly subscribed treaty to be an 'inalienable right,' the Security Council ... overstepped the bounds of its Chapter VII authority."

In sum, its post-Westphalian shift did not drive the UNSC's constitutionalization minor improvements regarding its decision-making procedures notwithstanding — but rather indicates that the UNSC used its far-reaching powers in order to establish authoritarian sub-orders constituted in an autocratic and operating in an arbitrary fashion.

\section{EU economic system}

While the EU economic system has gone beyond traditional intergovernmentalism from the very beginning of the establishment of the European Economic Community (EEC) in 1957, it has experienced a remarkable transformation toward more and more supranationalism and has become a picture-book example of a post-Westphalian order ever since (Genschel and Jachtenfuchs, 2014; Sandholtz and Stone Sweet, 1998). First, as it concerned itself with the establishment of a common market — and not just a free-trade area - from the very beginning it always had the ability to take intrusive decisions to ensure the free movement of goods, capital, services, and labor. With the creation of the euro as a common currency, it even gained the authority to make decisions that substitute for and/or intervene in member states' monetary and fiscal policies. Second, EU member states pool more and more decision-making authority in the Council. Qualified majority voting has successively replaced unanimity voting as the dominant mode of decisionmaking in the Council. Third, EU member states have delegated authority to powerful supranational organs such as the European Commission, the European Central Bank (ECB), and the Court of Justice of the European Union (CJEU). This shift toward 
post-Westphalian supranationalism was accompanied by a process of constitutionalization that has gone further than in any other IO (Schimmelfennig et al., 2006), but nevertheless left space for authoritarian rule.

The constitution of authority in the EU has generally become more democratic. The EU commitment to democratic law-making was already implied in the 1957 founding treaties that provided for the establishment of a European Parliamentary Assembly, the predecessor of today's European Parliament. Since 1979, the Parliament is directly elected by universal suffrage every five years (Rittberger, 2005). While mainly an assembly with consultative status in the first decade of its existence, the European Parliament has undergone a remarkable transformation ever since. Beginning with the 1987 Single European Act, its powers in terms of its role as a legislature have expanded with each treaty revision. With the extension of the so-called ordinary legislative procedure to almost all areas with EU economic competencies through the Lisbon Treaty, the Parliament has become a legislature on equal footing with the Council. Today, the Parliament and Council can be considered as two chambers in a bicameral legislative branch, with powers being equally distributed between both chambers (Schimmelfennig et al., 2006). However, the extent of supranational authority that the EU is exercising also creates a huge demand for democratic legitimacy that is said not to be fully accommodated in the current structures (Follesdal and Hix, 2006). Nevertheless, the EU order gives European citizens the opportunity to make their interests heard not only through their state representatives, but also through both public deliberations and traditional parliamentary representation.

Also, with respect to the legal constraints on authority, the EU can generally be considered constitutionalized. The 1957 founding treaties already committed the EU (then EEC) to a judicialized order based on rule-of-law principles (Alter, 2001). To ensure a joint authoritative interpretation of European law, the forerunner of today's CJEU, the European Court of Justice (ECJ), was established as a politically independent judiciary. While certainly not meant to become a constitutional court, the treaties gave member states direct access to the court if they deemed that European institutions acted beyond their mandate, as defined by the treaties (Rasmussen, 1998: 43). They also gave European citizens indirect access to the ECJ through the preliminary rulings procedure, through which the ECJ established both the direct effect of European law in the domestic legal system of EU member states and the supremacy of European law over domestic legal provisions of EU member states (Alter, 2001). Moreover, with the 2000 Charter of Fundamental Rights, the ECJ also gained the authority to strike down EU acts that contravene citizens' fundamental rights. Thus, to defend their rights against both EU member states and EU institutions, European citizens have direct or indirect access to judicial review by an independent court. In addition, the member states themselves can also rely on the CJEU as a legal remedy against allegedly unlawful interferences by EU institutions.

Overall, the transformation of the EU toward post-Westphalia was accompanied by a process of constitutionalization, which institutionalized both democratic and rule-of-law principles to an extent unprecedented in IOs. Yet, as the following analysis of its measures to cope with the euro crisis will show, Europe's post-Westphalian shift also brought authoritarian tendencies to the fore. We analyze: first, the EIP; second, the emergency credit facilities; and, third, the ECB's Outright Monetary Transactions (OMT) program. 
The Excessive Imbalances Procedure. With the so-called EIP, the EU established a partially authoritarian order. With regard to the constitution of authority, it is partially autocratic because the EIP's establishment by secondary law unduly undermined the EU authority structure, as established by the primary law of the treaties (Bast and Rödl, 2012; Joerges and Weimer, 2013). The EIP, which is generally designed to correct macroeconomic imbalances among the euro members, was introduced in 2011 by a "six-pack" of regulations strengthening the European framework for common economic governance. Most importantly, Regulation 1174/2011 allows for financial sanctions against states that suffer from huge current account deficits but do not comply with the corrective measures "recommended" by the Commission. The regulation thus turned the EU authority to issue non-binding recommendations into the authority to issue recommendations whose disregard can lead to financial sanctions, thus making them binding commitments. Moreover, for this purpose, the regulation also invented a decision-making procedure through secondary law that is not provided for in the primary law of the treaties and that unduly alters the relative powers between the Council and Commission (Bast and Rödl, 2012: 275-277). While, according to the treaties, the Council adopts proposals from the Commission by a qualified majority, Regulation 1174/2011 stipulates that a Commission proposal to employ financial sanctions is automatically adopted if not rejected by a qualified majority within 10 days. This reversed qualified majority voting obviously gives Commission proposals much more weight while reducing the Council's decision-making power: "In effect, this amounts to a constitutional revolution" (Scharpf, 2013: 136).

Moreover, the EIP hardly provides legal constraints on authority and can thus be regarded as partially arbitrary. The EIP gives the Commission almost full discretion over the corrective measures recommended if it has established that a member suffers from a huge current account deficit. Regulation 1176/2011 explicitly states that the Commission's recommendations "should cover the main economic policy areas, potentially including fiscal and wage policies, labour markets, product and services markets and financial sector regulation." It thus not only extends EU competencies to areas in which it has hardly any competencies according to the treaties, but also sets no substantive legal limit to what the Commission may recommend. As Scharpf $(2013: 136,139)$ puts it: "the EIP will establish a broadly discretionary regime of supranational economic supervision and management" that must "operate without any predefined rules." Furthermore, as Regulation 1174/2011 gives the Commission full discretion over the assessment as to whether a member state has complied with its recommended measures, the Commission also has full discretion over the use of financial sanctions against "noncompliant" states. Member states' budgetary autonomy and their basic right to decide on their proper economic policies no longer pose constraints for the Commission's authority (Joerges and Weimer, 2013). To be sure, the respective states may invoke the CJEU, but given that the EIP regulations provide the Commission with ample discretion in carrying out the program, it is unlikely that the CJEU will find any conceivable Commission recommendation or any related financial sanction in violation of European law.

The emergency credit facilities. The emergency credit facilities established by the EU in order to save financially distressed euro states from bankruptcy also show traits of an authoritarian order. This holds for the constitution of authority because all the three 
emergency facilities - the European Financial Stabilization Mechanism (EFSM), the European Financial Stability Facility (EFSF), and the European Stability Mechanism (ESM) - can be considered as being at odds with the "no bail-out clause" of Article 125(1) of the Treaty on the Functioning of the European Union (TFEU), which provides that neither the EU nor any member state shall be liable for or assume the commitments of another member (Ruffert, 2011; Ryvkin, 2012; Sester, 2012: 174-175). By endowing the emergency facilities with their own legal personality and thus absorbing debts from the troubled economies not directly, but only indirectly, the EU and its members may have managed to avoid open violation of the "no bail-out clause." In fact, in the "Pringle case," the CJEU judged the ESM to be in line with the treaties. Yet, the credit facilities substantially modify Europe's economic constitution (Joerges, forthcoming). Arguably, the CJEU was facing the question:

Should the "no bailout" rule be strictly observed leading to the likely implosion of the euro and the resulting dire economic consequences - dura lex, sed lex? Or, in light of the exceptional circumstances, should the bailout prohibition of Art 125 TFEU be disregarded in order to save the EU's most prestigious symbol, the euro - a Schmittian Ausnahmezustand? (Van Malleghem, 2013: 161, emphasis in original)

Moreover, as they do not provide for proper constraints on authority, the operation of the emergency credit facilities is partially arbitrary, too. The emergency facilities may only save states from bankruptcy if the respective Eurozone member is willing to accept strict fiscal conditionalities, as laid down in a Memorandum of Understanding. Yet, while de jure the result of negotiations between the respective state and the Commission in consultation with the ECB, de facto these conditions come close to an austerity dictate by the so-called Troika, comprised of the European Commission, the ECB and the International Monetary Fund (IMF), which provides the expertise for these negotiations. There are hardly any legal limits to what the Troika and thus the emergency credit facilities may require from states that are under their support programs. The Troika has indeed forced draconian fiscal measures on to indebted Eurozone member states such as Greece, Portugal, and Ireland, which were thus stripped of their fiscal sovereignty and budgetary autonomy. As Andreas Fischer-Lescano (2014) points out, the Troika even goes so far as to micromanage complete overhauls of labor and employment law, as well as cutbacks of public goods provisions ranging from the sectors of health to education. According to his legal analysis, these practices violate a broad canon of economic and social human rights. Except for the most fundamental human rights, the operation of the credit facilities thus seems to be hardly subject to legal constraints. ${ }^{10}$

The ECB Outright Monetary Transactions program. The OMT program of the ECB is another example of authoritarian traits in the EU. The constitution of authority regarding the OMT program comes close to being autocratic. With its 6 September 2012 decision to extend its Securities Market Programme (SMP), running since 2010 to buy, if necessary, an unlimited amount of government bonds from financially distressed states in the Eurozone, the ECB unduly seized competencies through executive self-empowerment (Homburg, 2012: 673). While the program might have been necessary to save the euro as a common currency, it is questionable whether it lies within the ECB's mandate, as 
defined by the treaties, because Article 123 of the TFEU explicitly bars the direct purchase of government bonds by the ECB (Duncan, 2013; Sester, 2012). While the ECB underlined that it would only buy from the secondary not from the primary market, others argue that the OMT program still violates the purpose behind Article 123, "which most experts agree was designed to be a general prohibition on ECB monetary financing of Eurozone government debt" (Duncan, 2013: 206). ${ }^{11}$ Besides the questionable compatibility with Article 123 of the TFEU, the OMT program also stretches the ECB's strictly monetary mandate to include fiscal matters (Menéndez, 2013: 513-514). The ECB argues that the program is within its mandate as it is not meant to reduce refinancing costs of the respective states per se, but to do so in order to enhance the functioning of the monetary policy transmission mechanism partially disrupted by the crisis (Schorkopf, 2013). The fact, however, that the ECB attaches the strict conditionality of an EFSF or ESM program to OMTs casts doubts on the sincerity of this claim. The German Federal Constitutional Court (FCC) therefore qualified the program as a fiscal policy measure paralleling the emergency credit facilities, which aim at the reduction of Eurozone members' refinancing costs to save them from bankruptcy (FCC Press release no. 9/2014, 7 February 2014).

As far as the legal constraints on the program's operation are concerned, the regime could possibly be termed partially arbitrary. If we follow the arguments advanced by one of the claimants in the case before the FCC, the OMT program severely undermines member states' fiscal autonomy (Murswiek, 2012: 36). It is held that if the ECB buys deficit countries' government bonds, it automatically creates financial obligations for the remaining Eurozone members. In case of bankruptcy of one or several deficit countries, financial burdens for the domestic budgets of other Eurozone countries are created. The ECB may thus autonomously accumulate enormous risks for the domestic budgets of Eurozone countries without parliamentary oversight — suspending member states' budgetary autonomy. However, it is also possible that the operation of the OMT program will be judicially restrained. In fact, the FCC submitted the ECB case to the CJEU for a preliminary ruling in February 2014 and there seems to be room for a restrictive interpretation in the light of the treaties that - if adopted by the CJEU - could base the program on the rule of law. Whether or not the CJEU will dare to defy the alleged political necessities of the crisis remains to be seen (Everson and Joerges, 2013).

In sum, as opposed to the UN security system, the post-Westphalian shift in the EU comes with a substantial constitutionalization process. Yet, in the context of the euro crisis, authoritarian orders have emerged that function according to a decisionist logic.

\section{Conclusion}

Our analysis of the UN security and the EU economic systems underlines that, as opposed to what is usually assumed, the current post-Westphalian shift does not automatically result in the constitutionalization of IO authority. Our "case studies" of the UN counterterrorism and non-proliferation regimes, as well as of EU policies during the euro crisis, clearly indicate that IOs may "slip" into (partially) authoritarian patterns. Yet, at the same time, it cannot be claimed that a post-Westphalian shift always provokes authoritarian IOs. The remarkable level of constitutionalization in the EU and also, but to a much 
lesser degree, the constitutionalist tendencies in the UN suggest that IO authority can be constitutionalized, at least in principle. Evidence from our analysis thus suggests that the shift toward post-Westphalia simultaneously drives the emergence of both constitutionalized and authoritarian orders. In other words, as in other institutions including the nation-state, constitutionalism and authoritarianism may be seen as effects of one and the same cause, namely, an increase of authority.

Moreover, our analysis also lends credence to the conceptual claim that authoritarian orders - like their constitutionalized counterparts - are orders of the same kind. As opposed to how they are analyzed so far, authoritarian IO measures are not always simply singular episodes of revocable IO misconduct (see also White, 2013: 16). While introduced as emergency measures and justified by exceptional necessity, our empirical analysis demonstrates that IOs carve out firmly institutionalized authoritarian orders that coexist with their constitutionalized counterparts. In addition, the evidence shows that authoritarian IO orders follow a common logic: in diametrical opposition to the constitutionalist logic according to which IO authority needs to be democratically constituted and constrained by the rule of law, this authoritarian logic entails that IO authority is autocratically constituted while operating arbitrarily without constraints. Therefore, our conceptualization of IO authority enabled us to treat not only constitutionalized, but also authoritarian, IO orders as belonging to one and the same class, respectively, and to conceive them as the poles of a gradual scale of IO-based post-Westphalian orders.

What does this tell us about post-Westphalia? Based on our analysis of the UN security and EU economic systems, it might be tempting to describe the post-Westphalian order simply as a "hybrid" of constitutionalism and authoritarianism. However, this description would miss the most important point! Post-Westphalia is inhabited by a plurality of fundamentally contradictory orders coexisting in parallel structures. Coexisting IOs may be constitutionalized or authoritarian, and - as the examples of the EU and the UN (albeit to a lesser extent) show - even within one and the same IO (sub-)order, there can be spheres of authority committed to the rule of law and democracy next to others reined by executive discretion and autocracy. It is this plurality of fundamentally contradictory (sub-)orders that seems to characterize the emerging post-Westphalian orders, which in themselves continue to coexist with largely Westphalian (sub-)orders.

This characterization of post-Westphalia opens avenues for further research. A first set of research questions is descriptive. It aims at the investigation of authoritarian and constitutional tendencies in the emerging post-Westphalian order. Where do we find constitutionalist and where do we find authoritarian tendencies? More specifically, one should ask: which IOs with supranational authority have become constitutionalized in which areas, and which IOs have gone authoritarian in which areas? A second set of research questions relates to the conditions under which post-Westphalian orders tend to lean toward constitutionalist and authoritarian principles, respectively. More specifically, one could ask: does the distribution of power among IO members pave the way into a constitutionalist or authoritarian direction? Does the social construction of the issue that the IO is dealing with — for instance, its securitization — "determine" the route toward constitutionalism or authoritarianism? Or, are institutional path dependencies responsible for the trajectory that an IO embarks upon? Most importantly, a third set of research questions regards the dynamic interplay of constitutionalist and authoritarian 
tendencies in IOs. Is the emergence of authoritarian orders likely to "contaminate" adjacent constitutional orders in some form of horizontal ratchet effect? Or, is the emergence of authoritarian orders likely to produce counter-reactions that then trigger further constitutionalization - a form of constitutional dialectic? Furthermore, how much preexisting constitutionalization is required to roll back authoritarian tendencies given that "unlike states which may have a populist or democratic counter-weight to pull back the concentration of power, such forces are far more dispersed and frequently absent in international organizations" (Gross and Ní Aoláin, 2006: 404)? If this article contributes to paving the way for a research program that addresses these — and related — questions, then it has fulfilled its main purpose.

\section{Acknowledgments}

Earlier versions of this article were presented at the 2013 Annual Convention of the International Studies Association in San Francisco, USA, the 2013 workshop "Herrschaft in den Internationalen Beziehungen" at the University of Frankfurt, Germany, as well as in seminars at the WZB Berlin Social Science Center and at Ludwig-Maximilians-Universität Munich's Geschwister-SchollInstitute. For helpful comments, we thank the participants in these forums, two anonymous reviewers, as well as Sophie Eisentraut, Tine Hanrieder, Nico Krisch, Andreas Kruck, Mattias Kumm, Karolina Milewicz, Lou Pauly, Alexander Spencer, Sidney Tarrow, Antje Wiener, and Michael Zürn. We also thank Tobias Müller for valuable research assistance.

\section{Funding}

This research received no specific grant from any funding agency in the public, commercial, or not-for-profit sectors.

\section{Notes}

1. This obviously reflects a conventionalized conception of the Westphalian order (Krasner, 1999; Osiander, 2001) and thus also of its post-Westphalian counterpart.

2. Note that we define IOs not as supranational bureaucracies (Barnett and Finnemore, 2004), but as "entities created with sufficient organizational structure and autonomy to provide formal, ongoing, multilateral processes of decisionmaking between states, along with the capacity to execute the collective will of their members (states)" (Volgy et al., 2008: 851). IOs can thus be understood as institutions with legislative, executive, and judicial bodies, each of which can be organized in either a supranational or intergovernmental fashion.

3. Political authority can be conceptualized as an actor's ability to evoke the rule-addressees' propensity to comply with its collectively binding decisions on a voluntary basis (Barnett and Finnemore, 2004: 7; Zürn et al., 2012: 82-88).

4. For recent contributions to the normative debate on (global) constitutionalism and authoritarianism, see Dobner and Loughlin (2010), Posner and Vermeule (2011), and Gill and Cutler (2014). Our own normative position is that constitutionalized and authoritarian orders may produce substantively positive or negative policies. However, in terms of the procedures, we generally prefer constitutionalism over authoritarianism.

5. For more comprehensive overviews, see Alexander (1998) and Scheuermann (2006).

6. For the broader debate on the relationship between the rule of law and democracy, see Bellamy and Castiglione (1997).

7. Generally, we hold that the analytical framework is applicable to all IOs enjoying a minimum of supranational (political) authority. 
8. See, among others, the statements by the delegates of Angola, Algeria, the Philippines, and New Zealand in the debates preceding the adoption of Resolution 1540 (S/PV.4950 (2004) and S/PV.4956 (2004)).

9. The UNSC's arrogation of legislative competencies was criticized, inter alia, by Brazil, Pakistan, Peru, India, Cuba, Indonesia, Iran, and Malaysia, see S/PV.4950 (2004), at pp. 4, $15,20,23,30-32$.

10. Furthermore, since the ESM has expressly been created as an international institution outside the legal order of the EU, it is all the more questionable if avenues for legal protection and judicial review will be available to affected citizens.

11. In a similar vein, the German Federal Constitutional Court (FCC) regards the OMT decision as an act ultra vires (FCC Press release no. 9/2014, 7 February 2014).

\section{References}

Alexander L (ed.) (1998) Constitutionalism: Philosophical Foundations. Cambridge: Cambridge University Press.

Alexy R (1992) Begriff und Geltung des Rechts. Freiburg: K. Alber.

Alter KJ (2001) Establishing the Supremacy of European Law: The Making of an International Rule of Law in Europe. London: Earthscan.

Alvarez JE (1996) Judging the Security Council. American Journal of International Law 90: 1-39.

Arato J (2012) Constitutionality and constitutionalism beyond the state: Two perspectives on the material constitution of the United Nations. International Journal of Constitutional Law 10(3): 627-659.

Armingeon K, Milewicz K, Peter S et al. (2011) The constitutionalization of international trade law. In: Cottier T and Delimatsis P (eds) The Prospects of International Trade Regulation: From Fragmentation to Coherence. Cambridge: Cambridge University Press, pp. 69-102.

Asado M (2009) Security Council Resolution 1540 and international legislation. In: Komori $\mathrm{T}$ and Wellens K (eds) Public Interest Rules of International Law: Towards Effective Implementation. Farnham, Surrey: Ashgate, pp. 141-164.

Aust H (2008) Between self-assertion and deference: European courts and their assessment of UN Security Council resolutions. Anuario Mexicano de Derecho Internacional 8: 51-77.

Austin J (2005 [1885]) Lectures on Jurisprudence, or, The Philosophy of Positive Law. Clark, NJ: Lawbook Exchange.

Bantekas I (2003) The international law of terrorist financing. American Journal of International Law 97: 315-333.

Barnett M and Finnemore M (2004) Rules for the World: International Organizations in Global Politics. Ithaca, NY: Cornell University Press.

Bast J and Rödl F (2012) Jenseits der Koordinierung? Zu den Grenzen der EU-Verträge für eine Europäische Wirtschaftsregierung. Europäische Grundrechte-Zeitschrift 39(10-12): 269278.

Bellamy R and Castiglione D (1997) Review article: Constitutionalism and democracy — political theory and the American constitution. British Journal of Political Science 27(4): 595-618.

Biermann F, Pattberg P, Van Asselt H et al. (2009) The fragmentation of global governance architectures: A framework for analysis. Global Environmental Politics 9(4): 14-40.

Binder M (2008) The politicization of international security institutions: The UN Security Council and NGOs. WZB Discussion Paper SP IV 2008-305. Available at: bibliothek.wzb.eu/ pdf/2008/iv08-305.pdf (accessed 27 March 2013).

Blake D and Lockwood Payton A (2014) Voting rules in intergovernmental organizations: An interest-based explanation of institutional design. Unpublished manuscript. 
Cameron I (2005) Protecting legal rights: On the (in)security of targeted sanctions. In: Wallensteen $\mathrm{P}$ and Staibano C (eds) International Sanctions: Between Words and Wars in the Global System. London: Routledge, pp. 181-206.

Carlson GS (2008) An offer they can't refuse? The Security Council tells North Korea to re-sign the Nuclear Non-Proliferation Treaty. Columbia Journal of Transnational Law 46: 420-467.

Cass DZ (2005) The Constitutionalization of the World Trade Organization: Legitimacy, Democracy, and Community in the International Trading System. Oxford: Oxford University Press.

Chesterman S (2009) UNaccountable? The United Nations, emergency powers, and the rule of law. Vanderbilt Journal of Transnational Law 42: 1509-1541.

Chimni BS (2004) International institutions today: An imperial state in the making. European Journal of International Law 15: 1-37.

Cohen JL (2008) A global state of emergency or the further constitutionalization of international law: A pluralist approach. Constellations 15(4): 456-484.

Cohen JL (2012) Globalization and Sovereignty: Rethinking Legality, Legitimacy and Constitutionalism. Cambridge: Cambridge University Press.

Cortell AP and Peterson S (2006) Dutiful agents, rogue actors, or both? Staffing, voting rules, and slack in the WHO and WTO. In: Hawkins DG, Lake DA, Nielson DL et al. (eds) Delegation and Agency in International Organizations. Cambridge: Cambridge University Press, pp. $255-280$.

Cortright D and Lopez GA (2000) The Sanctions Decade: Assessing UN Strategies in the 1990s. Boulder, CO: Rienner.

Cronin B and Hurd I (2008) The UN Security Council and the Politics of International Authority. London: Routledge.

Deitelhoff N (2009) The discursive process of legalization: Charting islands of persuasion in the ICC case. International Organization 63(1): 33-65.

Deshman AC (2011) Horizontal review between international organizations: Why, how, and who cares about corporate regulatory capture. European Journal of International Law 22(4): $1089-1113$.

De Wet E (2001) Human rights limitations to economic enforcement measures under Article 41 of the United Nations Charter and the Iraqi sanctions regime. Leiden Journal of International Law 14(2): 277-300.

Dobner P and Loughlin M (eds) (2010) The Twilight of Constitutionalism? Oxford: Oxford University Press.

Dreher A, Gaston N, and Martens P (2008) Measuring Globalisation: Gauging its Consequences. Berlin: Springer.

Duncan E (2013) Legalizing European Central Bank bond purchases: How the ECB can protect its own legitimacy and the future of the Euro. George Washington International Law Review 45(1): 183-213.

Elberling B (2005) The ultra vires character of legislative action by the Security Council. International Organizations Law Review 2(2): 337-360.

Everson M and Joerges C (2013) Who is the guardian for constitutionalism in Europe after the financial crisis? LSE "Europe in Question" discussion paper series. Available at: http:// papers.ssrn.com/sol3/papers.cfm?abstract_id=2287111 (accessed 25 September 2013).

Fassbender B (1998) The United Nations Charter as constitution of the international community. Columbia Journal of Transnational Law 36(3): 529-619.

Fassbender B (2006) Targeted sanctions imposed by the UN Security Council and due process rights: A study commissioned by the UN Office of Legal Affairs and follow-up action by the United Nations. International Organizations Law Review 3: 437-485. 
Fidler DP (2004) Constitutional outlines of public health's “new world order.” Temple Law Review 77(2): 247-290.

Fischer-Lescano A (2014) Human Rights in Times of Austerity Policy: The EU Institutions and the Conclusion of Memoranda of Understanding. Baden-Baden: Nomos.

Fischer-Lescano A and Teubner G (2004) Regime-collisions: The vain search for legal unity in the fragmentation of global law. Michigan Journal of International Law 25(4): 999-1046.

Fischer-Lescano A, Löhr T, and Tohidipur T (2009) Border controls at sea: Requirements under international human rights and refugee law. International Journal of Refugee Law 21: 256-296.

Follesdal A and Hix S (2006) Why there is a democratic deficit in the EU: A response to Majone and Moravcsik. Journal of Common Market Studies 44(3): 533-562.

Fremuth M and Griebel J (2007) On the Security Council as a legislator: A blessing or a curse for the international community? Nordic Journal of International Law 76: 339-361.

Fry JD (2008) Dionysian disarmament: Security Council WMD coercive disarmament measures and their legal implications. Michigan Journal of International Law 29: 197-291.

Genschel P and Jachtenfuchs M (2014) Beyond the Regulatory Polity? The European Integration of Core State Powers. Oxford: Oxford University Press.

Genschel P and Zangl B (2014) State transformations in OECD countries. Annual Review of Political Science 17: 337-354.

Gill S and Cutler C (2014) New constitutionalism and world order: General introduction. In: Gill S and Cutler C (eds) New Constitutionalism and World Order. New York, NY: Cambridge University Press, pp. 1-21.

Gross O and Ní Aoláin F (2006) Law in Times of Crisis: Emergency Powers in Theory and Practice. Cambridge: Cambridge University Press.

Habermas J (1996) Between Facts and Norms: Contributions to a Discourse Theory of Law and Democracy. Cambridge, MA: MIT Press.

Hanrieder T and Kreuder-Sonnen C (2014) WHO decides on the exception? Securitization and emergency governance in global health. Security Dialogue 45(4): 331-348.

Hart HLA (1994) The Concept of Law. Oxford: Oxford University Press.

Hawkins DG, Lake DA, Nielson DL et al. (2006) Delegation and Agency in International Organizations. Cambridge: Cambridge University Press.

Held D (1999) Global Transformations: Politics, Economics and Culture. Stanford, CA: Stanford University Press.

Heupel M (2007) Adapting to transnational terrorism: The UN Security Council's evolving approach to terrorism. Security Dialogue 38(4): 477-499.

Heupel M (2013) With power comes responsibility: Human rights protection in United Nations sanctions policy. European Journal of International Relations 19(4): 773-796.

Hobbes T (2008 [1651]) Leviathan. Oxford: Oxford University Press.

Höffe O (1987) Politische Gerechtigkeit: Grundlegung einer Kritischen Philosophie von Recht und Staat. Frankfurt am Main: Suhrkamp.

Hoffmann J (2008) Terrorism blacklisting: Putting European human rights guarantees to the test. Constellations 15(4): 543-560.

Homburg S (2012) Der neue Kurs der Europäischen Zentralbank. Wirtschaftsdienst 92(10): 673677.

Hooghe L, Marks G, Lenz T et al. (forthcoming) Scale and Community: The Purpose and Design of International Organizations. Oxford: Oxford University Press.

Hudson A (2007) Not a great asset: The UN Security Council's counter-terrorism regime: Violating human rights. Berkeley Journal of International Law 25: 203-227.

Joerges $\mathrm{C}$ (forthcoming) Three transformations of Europe and the search for a way out of its crisis. In: Joerges C and Glinski C (eds) The European Crisis and the Transformation of 
Transnational Governance: Authoritarian Managerialism versus Democratic Governance. Oxford: Hart Publishing.

Joerges C and Weimer M (2013) A crisis of executive managerialism in the EU: No alternative? In: Trubek DM, De Búrca G, Kilpatrick C et al. (eds) Critical Legal Perspectives on Global Governance: Liber Amicorum David M. Trubek. Oxford: Hart Publishing, pp. 295-322.

Johnstone I (2008) Legislation and adjudication in the UN Security Council: Bringing down the deliberative deficit. American Journal of International Law 102: 275-308.

Joyner D (2012) The Security Council as a legal hegemon. Georgetown Journal of International Law 43: 225-257.

Kant I (2007 [1795]) Perpetual Peace: A Philosophical Essay. Minneapolis: Filiquarian.

Kant I (2009 [1797]) The Metaphysics of Morals (trans. Mary Gregor). Cambridge: Cambridge University Press.

Kay RS (1998) American constitutionalism. In: Alexander L (ed.) Constitutionalism: Philosophical Foundations. Cambridge: Cambridge University Press, pp. 16-63.

Kelsen H (1931) Wer soll Hüter der Verfassung sein? Die Justiz IV: 576-628.

Kelsen H (2003 [1952]) Principles of International Law. Clark, NJ: The Lawbook Exchange, Ltd.

Keohane RO, Macedo S, and Moravcsik A (2009) Democracy-enhancing multilateralism. International Organization 63(1): 1-31.

Klabbers J, Peters A, and Ulfstein G (2009) The Constitutionalization of International Law. Oxford: Oxford University Press.

Koskenniemi M (1995) The police in the temple: Order, justice and the UN: A dialectical view. European Journal of International Law 6: 325-348.

Krasner SD (1999) Sovereignty: Organized Hypocrisy. Princeton, NJ: Princeton University Press.

Kreuder-Sonnen C (2012) Der Globale Ausnahmezustand: Carl Schmitt und die Anti-TerrorPolitik des UN Sicherheitsrates. Baden-Baden: Nomos.

Krisch N (2010) Beyond Constitutionalism: The Pluralist Structure of Postnational Law. Oxford: Oxford University Press.

Krisch N (2012) Chapter VII powers: The general framework. Articles 39 to 43. In: Simma B, Nolte G, Khan D et al. (eds) The Charter of the United Nations: A Commentary. Oxford: Oxford University Press, pp. 1237-1356.

Kumm M (2004) The legitimacy of international law: A constitutionalist framework of analysis. European Journal of International Law 15(5): 907-931.

Lake DA (2007) Delegating divisible sovereignty: Sweeping a conceptual minefield. Review of International Organizations 2(3): 219-237.

Machiavelli N (2008 [1532]) The Prince. Oxford: Oxford University Press.

Malone D (2004) The UN Security Council: From the Cold War to the 21st Century. Boulder, CO: Rienner.

Martínez LMH (2008) The legislative role of the Security Council in its fight against terrorism: Legal, political, and practical limits. International and Comparative Law Quarterly 57: $333-359$.

Matheson MJ (2006) Council Unbound: The Growth of UN Decision Making on Conflict and Postconflict Issues After the Cold War. Washington, DC: United States Institute of Peace Press.

May C (2014) The rule of law as the grundnorm of the new constitutionalism. In: Gill S and Cutler C (eds) New Constitutionalism and World Order. New York, NY: Cambridge University Press, pp. 63-75.

Menéndez AJ (2013) The existential crisis of the European Union. German Law Journal 14(5): $453-526$. 
Murswiek D (2012) Beschwerdebegründung für Beschwerdeführer Dr. Peter Gauweiler im Verfassungsbeschwerdeverfahren 2 BvR 1390/12 vom 11.10.2012. Available at: http://www. jura.uni-freiburg.de/institute/ioeffr3/forschung/papers/murswiek/klageerweiterung-ezb-target.pdf (accessed 23 September 2013).

Naudé Fourie A (2009) The World Bank Inspection Panel and Quasi-Judicial Oversight: In Search of the “Judicial Spirit” in Public International Law. Utrecht: Eleven International Publishing.

Osiander A (2001) Sovereignty, International Relations, and the Westphalian myth. International Organization 55(2): 251-287.

Paul JA (2004) Working with nongovernmental organizations. In: Malone D (ed.) The UN Security Council: From the Cold War to the 21st Century. Boulder, CO: Rienner, pp. 373-387.

Peters A (2006) Compensatory constitutionalism: The function and potential of fundamental international norms and structures. Leiden Journal of International Law 19: 579-610.

Petersmann E (1996/1997) Constitutionalism and international organizations. Northwestern University Journal of International Law \& Business 17: 398-469.

Posner EA and Vermeule A (2011) The Executive Unbound: After the Madisonian Republic. New York, NY: Oxford University Press.

Rajkovic NM (2012) "Global law" and governmentality: Reconceptualizing the "rule of law" as rule "through" law. European Journal of International Relations 18(1): 29-52.

Rasmussen H (1998) The European Court of Justice. Copenhagen: GadJura.

Raustiala K and Victor DG (2004) The regime complex for plant genetic resources. International Organization 58(2): 277-309.

Rittberger B (2005) Building Europe's Parliament: Democratic Representation beyond the Nation State. Oxford: Oxford University Press.

Rosand E (2004) The Security Council as "global legislator": Ultra vires or ultra innovative? Fordham International Law Journal 28: 542-590.

Ruffert M (2011) The European debt crisis and European Union law. Common Market Law Review 48: $1777-1806$.

Ryvkin B (2012) Saving the Euro: Tensions with European treaty law in the European Union's efforts to protect the common currency. Cornell International Law Journal 45: 227-255.

Sandholtz W and Stone Sweet A (1998) European Integration and Supranational Governance. Oxford: Oxford University Press.

Scharpf FW (2013) Monetary union, fiscal crisis and the disabling of democratic accountability. In: Streeck W and Schäfer A (eds) Politics in the Age of Austerity. Cambridge: Polity, pp. 108-142.

Scheuermann WE (2006) Survey article: Emergency powers and the rule of law after 9/11. Journal of Political Philosophy 14(1): 61-84.

Schimmelfennig F and Rittberger B (2006) Explaining the constitutionalization of the European Union. Journal of European Public Policy 13(8): 1148-1167.

Schimmelfennig F, Rittberger B, Bürgin A et al. (2006) Conditions for EU constitutionalization: A qualitative comparative analysis. Journal of Public Policy 13(8): 1168-1189.

Schmitt C (1996 [1931]) Der Hüter der Verfassung. Berlin: Duncker \& Humblot.

Schmitt C (2014 [1928]) Dictatorship: From the Origin of the Modern Concept of Sovereignty to Proletarian Class Struggle (trans. Michael Hoelzl and Graham Ward). Cambridge: Polity.

Schneiderman D (2000) Investment rules and the new constitutionalism. Law and Social Inquiry 25(3): 757-787.

SchorkopfF(2013)StellungnahmederEuropäischenZentralbankim Verfassungsbeschwerdeverfahren 2 BvR 1390/12, 2BvR 1439/12 und 2 BvR 1824/12 sowie im Organstreitverfahren 2 BvE 6/12 vom 16.01.2013. Available at: www.handelsblatt.com/downloads/8135244/3/EZB\% 20Gutachten (accessed 23 September 2013). 
Schott J (2007) Chapter VII as exception: Security Council action and the regulative ideal of emergency. Northwestern University Journal of International Human Rights 6: 24-80.

Schweitzer H (2013) Judicial review in EU competition law. In: Lianos I and Geradin D (eds) Handbook of European Competition Law: Enforcement and Procedure. Cheltenham: Edward Elgar, pp. 491-538.

Sester P (2012) The ECB's controversial Securities Market Programme (SMP) and its role in relation to the modified EFSF and the future ESM. European Company and Financial Law Review 9(2): 156-178.

Shaygan F (2008) La compatibilité des sanctions économiques du Conseil de sécurité avec les droits de l'homme et le droit international humanitaire. Bruxelles: Bruylant.

Stark J (2012) The ECB's OMT's (Out-of-Mandate Transactions). The International Economy (Autumn): 52-55.

Stone Sweet A (2000) Governing with Judges: Constitutional Politics in Europe. Oxford and New York, NY: Oxford University Press.

Szasz PC (2002) The Security Council starts legislating. American Journal of International Law 96: 901-904.

Uhlin A and Tallberg J (2012) Civil society and global democracy: An assessment. In: Archibugi D, Koenig-Archibugi M, and Marchetti R (eds) Global Democracy: Normative and Empirical Perspectives. Cambridge and New York, NY: Cambridge University Press, pp. 210-232.

Van Malleghem P (2013) Pringle: A paradigm shift in the European Union's monetary constitution. German Law Journal 14(1): 141-168.

Volgy TJ, Fausett E, Grant KA et al. (2008) Identifying formal intergovernmental organizations. Journal of Peace Research 45(6): 849-862.

Wendt A (1999) Social Theory of International Politics. Cambridge and New York, NY: Cambridge University Press.

White J (2013) Emergency Europe. Political Studies. Available at: http://onlinelibrary.wiley.com/ doi/10.1111/1467-9248.12072/abstract (accessed 25 September 2014).

Wiener A, Lang Jr AF, Tully J et al. (2012) Editorial: Global constitutionalism: Human rights, democracy and the rule of law. Global Constitutionalism 1(1): 1-15.

Zangl B (2008) Judicialization matters! A comparison of dispute settlement under GATT and the WTO. International Studies Quarterly 58: 825-854.

Zürn M (2004) Global governance and legitimacy problems. Government and Opposition 39(2): 260-287.

Zürn M, Binder M, and Ecker-Ehrhardt M (2012) International authority and its politicization. International Theory 4(1): 69-106.

\section{Author biographies}

Christian Kreuder-Sonnen is Research Associate at the WZB Berlin Social Science Center and a $\mathrm{PhD}$ candidate at the Berlin Graduate School for Transnational Studies (BTS), Germany. His dissertation analyzes the emergency politics of international organizations from a constitutionalist perspective. He is the author of Der Globale Ausnahmezustand. Carl Schmitt und die Anti-TerrorPolitik des UN-Sicherheitsrates (Nomos, 2012). His most recent article has appeared in Security Dialogue.

Bernhard Zangl is Professor of Global Governance and Public Policy at Ludwig-MaximiliansUniversität München (LMU), Germany. He is especially interested in the changing role of international institutions and its effects on both the international system in general and its most fundamental entity, the modern state, more specifically. His research has been published in International 
Studies Quarterly, European Journal of International Relations, Annual Review of Political Science, Journal of International Relations and Development, Zeitschrift für Internationale Beziehungen, and Politische Vierteljahresschrift, among others. 